\title{
Widespread seawater circulation in 18-22 Ma oceanic crust: Impact on heat flow and sediment geochemistry
}

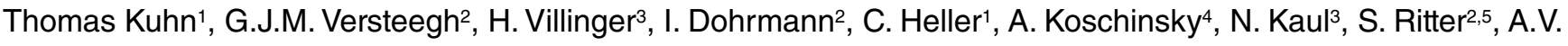 \\ Wegorzewski ${ }^{1}$, and S. Kasten ${ }^{2}$ \\ ${ }^{1}$ Federal Institute for Geosciences and Natural Resources (BGR), Stilleweg 2, 30655 Hannover, Germany \\ ${ }^{2}$ Alfred Wegener Institute Helmholtz Centre for Polar and Marine Research (AWI), Am Handelshafen 12, D-27570 Bremerhaven, Germany \\ ${ }^{3}$ Department of Geosciences, University of Bremen, P.O. Box 330440, 28334 Bremen, Germany \\ ${ }^{4}$ Department of Physics \& Earth Sciences, Jacobs University Bremen, Campus Ring 1, 28759 Bremen, Germany \\ 5Institute of Earth Sciences, Heidelberg University, Im Neuenheimer Feld 234, 69120 Heidelberg, Germany
}

\begin{abstract}
On the basis of heat-flow measurements, seismic mapping, and sediment pore-water analysis, we demonstrate widespread and efficient ventilation of the 18-22 Ma oceanic crust of the northeast equatorial Pacific Ocean. Recharge and discharge appear to be associated with basement outcrops, including seamounts and north-south-trending faults, along which sediment cover thins out and volcanic rocks are exposed. Low-temperature hydrothermal circulation through the volcanic crust leads to the reduction of heat flow through overlying sediments, with measured heat-flow values that are well below those expected from conductive cooling curves for lithosphere of this age. Typically, dissolved pore-water oxygen decreases from the sediment surface downward, reaching minimum values at mid-depth and rising again in the lower part of the cores investigated, clearly indicating oxygen-rich seawater circulation through the oceanic crust underneath the sediments. If the residence time of the circulating fluids in the upper crust is short or the fluid flux is large, oxic conditions may be preserved, and oxygen can diffuse upwards into the sediments. This process, leading to widespread oxic conditions in the near-basement sediments, may cause the oxidation of residual reduced material stored in the deeper sediments, resulting in downward fluxes of the reaction products into the basement and from there back into the oceans. Considering the widespread existence of this type of off-axis ventilation, the net effect of the resulting return flow of reaction products on biogeochemical cycles and element fluxes (e.g., carbon and nitrogen) may be very large.
\end{abstract}

\section{INTRODUCTION}

One of the important processes by which Earth loses internal heat is through cooling of the oceanic lithosphere (Sclater, 2003). At the axis of mid-ocean ridges without sediment cover, heat loss occurs due to focused or diffuse hydrothermal discharge. Farther away from the axis, on lithosphere older than ca. $1 \mathrm{Ma}$, heat-flow measurements in deep-sea sediments generally display values that are lower and more heterogeneous than those expected from conductive lithospheric cooling models (Hasterok et al., 2011, and references therein). These measurements indicate that hydrothermal fluids remove significant amounts of heat from the oceanic lithosphere in off-axis settings up to an age of ca. 65 Ma on average (Stein and Stein, 1992; Hasterok et al., 2011). Off-axis seamounts and other basement outcrops that protrude through low-permeability sediments offer important pathways for the transport of heat and fluids (Fisher, 2005).

The conclusion of Baker et al. (1991) that seawater circulates in the upper crust of the equatorial Pacific Ocean was predominantly based on the interpretation of pore-water profiles from
Deep Sea Drilling Project (DSDP) boreholes. They backed their conclusion by referring to six low heat-flow values from the same area (Sclater et al., 1976). Pore-water evidence for seawater circulation in oceanic basement was also presented by Mewes et al. (2016) for a transect of sediment cores retrieved at the flank of a seamount in the northeast equatorial Pacific Ocean. Here, we present the first comprehensive investigation including bathymetry, seismic, heat-flow, sedimentary pore-water, and solid-phase data in a typical ridge-flank setting (Fig. 1). We find compelling evidence for suppressed heat flow over a broad region resulting from advective heat extraction through numerous basement exposures at seamounts and faults.

\section{STUDY AREA AND METHODS}

The study area is located in the equatorial northeast Pacific Ocean $~ 900$ nautical miles $(1700 \mathrm{~km})$ southwest of Manzanillo, Mexico, and it belongs to the German license area for the exploration of manganese nodules granted by the International Seabed Authority in 2006 (Fig. 1; refer to www.isa.org.jm for an updated map with all license areas). Magnetic data indicate a crustal age of 18-22 Ma (Barckhausen et al., 2013). Water depths are 1460-4680 m, with an average of $4240 \mathrm{~m}$ (Rühlemann et al., 2011). The seafloor is characterized by deep-sea plains interspersed with NNW-SSE-oriented horst and graben structures that are several kilometers wide, tens of kilometers long, and 100-300 m high (Rühlemann et al., 2011; Fig. 1). Many extinct volcanoes (seamounts) rise a few hundred meters to almost $3000 \mathrm{~m}$ over the surrounding abyssal plains. They are 3-30 $\mathrm{km}$ in diameter and seem to appear in clusters with an east-west-trending orientation (Rühlemann et al., 2011; Fig. 1).

During cruise SO-240 (May-June 2015) on the German research vessel SONNE, $636 \mathrm{~km}$ of single-channel seismic profiles were run perpendicular and parallel to the ridge and graben structures using one 3.4 L GI air gun and a 100-m-long, 16 channel streamer (Kuhn et al., 2015; Fig. 1). Apart from identifying tectonic structures of the upper crust, the seismic data were used to assess sediment thickness, with a resolution limit of $10 \mathrm{~m}$ due to the low main frequency of the air gun signal. High-resolution bathymetric data using the hull-mounted EM 122 multibeam echosounder system and internal sediment structures using the subbottom profiler ParaSound P70 were recorded together with the seismic data. Heat flow (Bremen heat-flow probe; Villinger et al., 2010) was mapped on 14 profiles (109 individual measurements), all collocated on seismic and ParaSound profiles. Long piston (KL) and gravity cores (SL; up to $13.5 \mathrm{~m}$ ) were taken at locations of heat-flow anomalies (Fig. 1; Table DR1 in the GSA Data Repository ${ }^{1}$ ). Oxygen in the retrieved sediments was determined onboard using amperometric Clark-type $\mathrm{O}_{2}$ sensors according to the procedure described

${ }^{1}$ GSA Data Repository item 2017261, sediment permeability and thickness, seismic and heat flow data, sediment and pore-water geochemistry, and a sidescan sonar image indicating mass wasting, is available online at http://www.geosociety.org/datarepository /2017/ or on request from editing@ geosociety.org. 


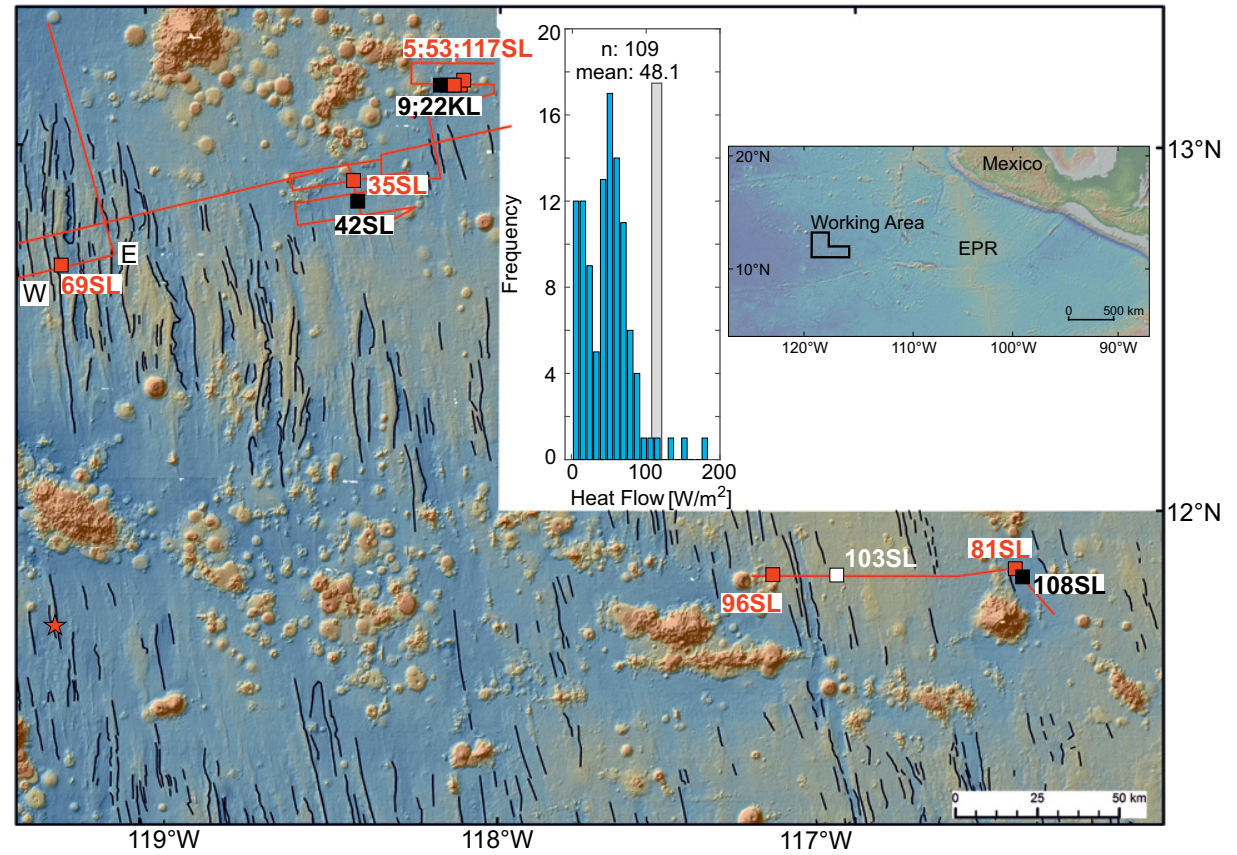

by Ziebis et al. (2012) and Mewes et al. (2014, 2016). Pore-water samples were retrieved by Rhizon samplers, diluted 1:10 and acidified with suprapure $1 \mathrm{M} \mathrm{HNO}_{3}$, and stored at $4{ }^{\circ} \mathrm{C}$ until analysis of dissolved manganese $\left(\mathrm{Mn}^{2+}\right)$ at the home laboratory at the Alfred Wegener Institute (Bremerhaven, Germany) using inductively coupled plasma-optical emission spectrometry (ICP-OES). For more technical details, see Kuhn et al. (2015).

Permeability of the deep-sea sediments was measured by constant-flow tests with a "Column TestStand" based on the German standard DIN 19683-9 (see Fig. DR1 and the Data Repository). Sediment down-core porosity was also measured to check for compaction according to the procedure described by Mewes et al. (2014).

\section{RESULTS}

\section{Hydro-Acoustic and Heat-Flow Data}

The hydro-acoustic mapping (bathymetry, subbottom profiler, seismics) showed sediment thicknesses between $0 \mathrm{~m}$ and $100 \mathrm{~m}$, with an average of $48 \mathrm{~m}$ (refer to Fig. DR2). Low to zero sediment thickness was detected at several locations along the NNW-SSE-trending ridges (Fig. 1). The basaltic basement may outcrop at these sites or is covered by less than $10 \mathrm{~m}$ of sediment (Fig. 2). Due to the small-scale roughness of the seafloor bathymetry, even ParaSound could not resolve $<10 \mathrm{~m}$ sediment cover. Seismic data revealed intense small-scale tectonics in the acoustic basement (layer 2A; Fig. 2). Except for a few isolated high values, the mean heat flow of $48.1 \mathrm{~mW} / \mathrm{m}^{2}$ is well below the $\sim 108-119 \mathrm{~mW} /$ $\mathrm{m}^{2}$ predicted for 18-22 Ma conductively cooling oceanic crust (see Figs. DR3 and DR4, and data in the Data Repository; Hasterok, 2013),
Figure 1. Bathymetry of study area based on EM 120 multibeam echosounder system data from previous cruises in northeast equatorial Pacific Ocean (Rühlemann et al., 2011). Black lines-lineaments detected in bathymetry; red lines-seismic profiles; red squares-sediment cores that are oxic throughout; black squares-cores with a suboxic zone at depth (see Fig. 3); W and E indicate the location of the seismic profile of Figure 2; red starposition of Figure DR6 (see text footnote 1). Permeability measurements were carried out on sediments from core 103SL. Insets: Location of study area $\sim 900$ nautical miles (1700 km) southwest off Mexico; EPR-East Pacific Rise. Histogram shows all heat-flow measurements from this study with mean value (48.1 $\mathrm{mW} / \mathrm{m}^{2}$ ) and range of lithospheric cooling predictions for 18-22 Ma oceanic crust (gray bar; Hasterok, 2013). and it also only $\sim 2 / 3$ of mean values reported for this crustal age (Fisher, 2005). The few heatflow values above the predicted value for conductive cooling are either related to faults in the basaltic basement (69SL; Fig. 2) or are close to a seamount (117SL; Fig. 3). In situ thermal conductivities are rather uniform $(0.83 \mathrm{~W} / \mathrm{Km}$; Fig. DR4), because the sediment composition in all study areas is very homogeneous. They consist of a mixture of siliceous ooze and deep-sea clay, except for stations 69SL and 117SL, where carbonate-rich sediments were found at greater down-core depth (Fig. DR5; Kuhn et al., 2015).

\section{Pore-Water Geochemistry}

In long sediment cores close to seamounts and close to larger fractures in the basaltic crust, sediments are oxic throughout, with $\mathrm{O}_{2}$ concentrations decreasing downward from the core top and upward from the bottom of the cores toward the middle part (53SL, 81SL, and 117SL in Fig. 3; 5SL, 35SL, 69SL, and 96SL in Fig. DR6). The

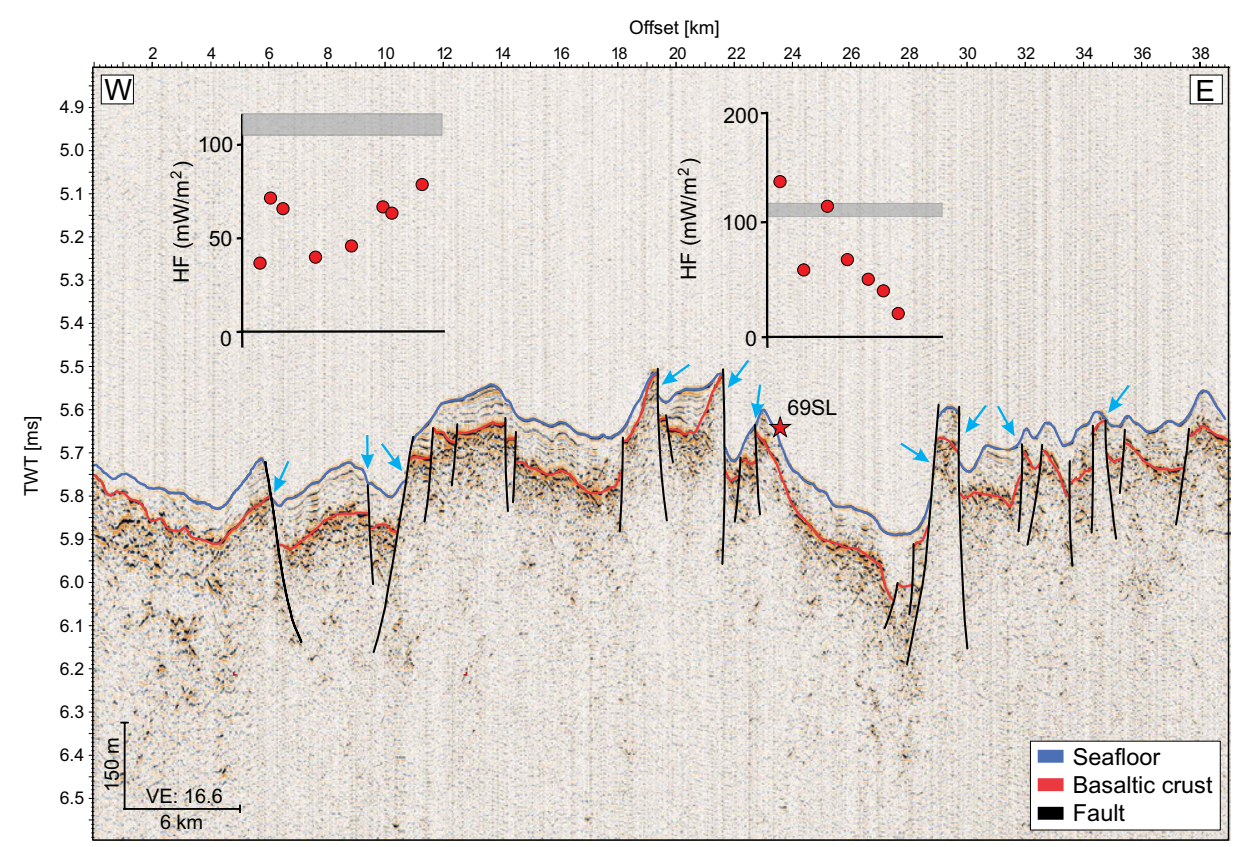

Figure 2. Processed seismic profile with suggested fault structures and heat-flow profiles. At some faults, basaltic basement is exposed to seafloor, enabling a direct hydrological link between seawater and permeable basaltic crust (blue arrows). Horizontal gray bars indicate range of lithospheric cooling predictions for 18-22 Ma oceanic crust (Hasterok, 2013). VEvertical exaggeration, TWT-two-way traveltime (R. Singh, 2017, personal commun.). 

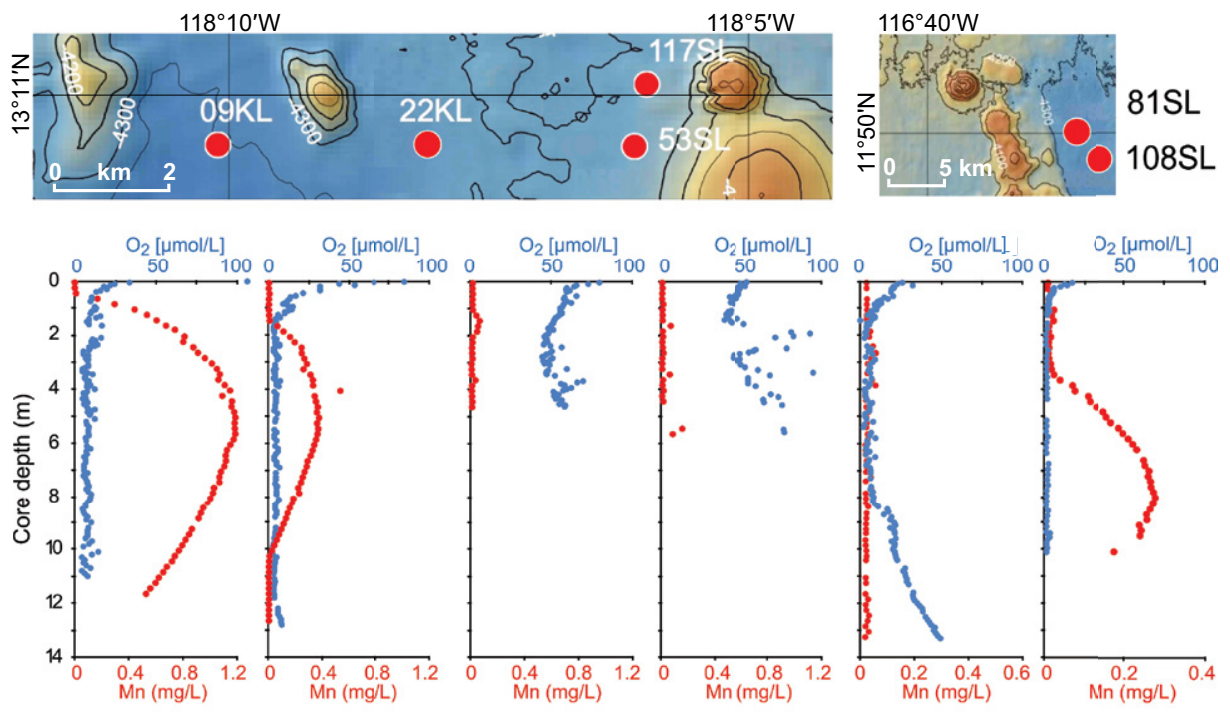

$9 \mathrm{KL}$

$22 \mathrm{KL}$

117SL

81SL

108SL

Figure 3. Pore-water concentration profiles of $\mathrm{O}_{2}$ and $\mathrm{Mn}^{2+}$ along a near-seamount, east-west transect (9KL-117SL), as well as at a site above a fracture in basaltic crust (81SL) and a site without such a fracture (108SL). See Figure 1 for location of cores. Isobaths denote $100 \mathrm{~m}$ depth intervals.

sediments overlying the basaltic crust are $\sim 10 \mathrm{~m}$ thick at sites 53SL and 117SL. Farther away from these locations and with increasing sediment thickness $(\sim 20 \mathrm{~m})$, the concentrations of $\mathrm{O}_{2}$ in the central parts of the retrieved cores decrease until these eventually are oxygen-free, i.e., suboxic (22KL in Fig. 3). In these oxygen-free sediment intervals, dissolved manganese $\left(\mathrm{Mn}^{2+}\right)$ is present at the highest concentrations. With further increasing sediment thickness, the retrieved sediments do not contain any dissolved $\mathrm{O}_{2}$ in their bottom part; however, the downward-decreasing pore-water $\mathrm{Mn}^{2+}$ concentrations clearly indicate that $\mathrm{O}_{2}$ is present deeper in the sediment $(9 \mathrm{KL}$ and 108SL in Fig. 3). Comparison of pore-water $\mathrm{O}_{2}$ and $\mathrm{Mn}^{2+}$ profiles for sediments taken above or near faults that extend from the basaltic crust into the lower part of the sediment package (69SL, 81SL) with nearby sediments from similar sites but without such an underlying fault $(09 \mathrm{KL}$, $22 \mathrm{KL}, 108 \mathrm{SL}$ ) shows that $\mathrm{O}_{2}$ penetrates much further from the basement upwards into the sediments where faults are present (Fig. 3).

\section{Permeability of the Sediments}

Permeability was measured on whole rounds of one sediment core at six different depths (103SL, Fig. 1). Permeability ranged between $1.4 \times 10^{-14} \mathrm{~m}^{2}$ and $7.8 \times 10^{-14} \mathrm{~m}^{2}$ (Fig. DR1), which is in the typical range of siliceous-rich sediments (Spinelli et al., 2004). The porosity of the sediments measured on several cores from the study area is rather constant $(\sim 85 \%)$, indicating that there was no or negligible compaction.

\section{DISCUSSION}

In intraplate settings, fluids may flow laterally through the basaltic basement at rates of $0.1-10 \mathrm{~m} / \mathrm{yr}$ if permeability is in the range of $10^{-12}$ to $10^{-11} \mathrm{~m}^{2}$ (Fisher and Becker, 2000). Deep-sea sediments generally have a low permeability $\left(<10^{-14} \mathrm{~m}^{2}\right.$; Spinelli et al., 2004), preventing large-scale vertical fluid advection through them. Therefore, basement outcrops and high basement permeability are necessary to permit seawater to recharge and discharge the basaltic basement. Seamounts, which protrude through low-permeability sediments, serve as conduits enabling the transport of fluids into the basaltic basement in off-axis settings (Fisher et al., 2003; Villinger et al., 2017). In model studies, smallsized seamounts (with a radius of several hundred meters and a radius/height ratio $<0.5$ ) can act either as fluid recharge or discharge sites at a crustal heat flow of $50-150 \mathrm{~mW} / \mathrm{m}^{2}$, whereas large seamounts tend to form convection cells within their seamount structure (Kawada et al., 2011; Winslow and Fisher, 2015).

Our heat-flow data, well below the values of pure conductive cooling, indicate that cold bottom water enters the basaltic crust and extracts heat. All cores from the vicinity of small seamounts (after criteria of Kawada et al., 2011) have dissolved $\mathrm{O}_{2}$ and $\mathrm{Mn}^{2+}$ concentration profiles indicating the flow of seawater in the basaltic crust underneath the sediments at these locations.

However, seawater recharge was not restricted to seamounts; it could also be detected near basaltic outcrops on the NNW-SSE-trending ridges (Figs. 1 and 2), suggesting spatially widespread heat extraction in the study area (Fisher et al., 2001; Hutnak and Fisher, 2007).

The near-surface sediments (upper 10-15 m) of the study area mainly consist of a mixture of siliceous ooze and pelagic clay (Fig. DR5). Because porosity and composition are rather constant, the hydraulic impedance (i.e., the permeability) is mainly dependent on sediment thickness. At an average thickness of $40 \mathrm{~m}$, mixtures of siliceous ooze and pelagic clay will have impedance values between $1 \times 10^{-15} \mathrm{~m}^{-1}$ (pure siliceous ooze) and $1 \times 10^{-16} \mathrm{~m}^{-1}$ (pure pelagic clay; Spinelli et al., 2004). Given these conditions, advective flow through the sediments may be inhibited, and lateral fluid flow may dominate in the permeable basaltic crust underneath. At sites with very thin sediment cover and/or faults along which the basaltic basement is exposed, seawater recharge and discharge may happen. This assumption is consistent with the local geological conditions of our study area (Fig. 2; Fig. DR3) and with the diffusion of $\mathrm{O}_{2}$ from the basement into the overlying sediments evidenced by all our sediment cores. Recharge and discharge at basement outcrops extract heat from the upper crust, resulting in temperatures a few degrees above bottom water temperature, which limits chemical reactions of the circulating fluid with the basaltic basement. Therefore, the fluids are oxic throughout, and upward $\mathrm{O}_{2}$ diffusion into the sediments occurs. Fluid seepage may only be possible through very thin sediments $(<10$ $\mathrm{m})$, as none of the pore water profiles indicates advective fluid flow through thicker sediments.

A prerequisite for fluid advection through the basaltic basement outside the influence of seamounts is a very thin sediment cover and/or outcropping basaltic crust. Obviously, there are several locations on the NNW-SSE ridges where this prerequisite is fulfilled. The reason for the low and variable sediment thickness over those ridges might be a combination of strong nearbottom currents and active tectonics. Numerous faults on the NNW-SSE ridges were identified by our seismic data (Fig. 2). Near-bottom current activity has been detected using sidescan sonar during previous cruises (Wiedicke-Hombach, 2010, personal commun.; Fig. DR7) and is further supported by the presence of hiatuses in the sediment cover of the study area (Mewes et al., 2014).

Our interpretation of the geophysical data is consistent with the pore-water geochemistry. In areas of low heat flow and thin sediment cover, the sediments are oxic throughout (53SL, 117SL in Fig. 3). In these sediments, dissolved $\mathrm{O}_{2}$ concentrations are high at the top and the bottom of the retrieved sediments and lower in-between. Such pore-water profiles can be explained by downward $\mathrm{O}_{2}$ diffusion from oxygen-rich seawater as well as upward $\mathrm{O}_{2}$ diffusion from oxygen-rich water migrating through the basaltic basement (Mewes et al., 2016; Mogollón et al., 2016; Ziebis et al., 2012).

With increasing sediment thickness, the $\mathrm{O}_{2}$ gradients get less steep, resulting in a slower diffusive flux. In combination with ongoing $\mathrm{O}_{2}$ consumption, this eventually leads to a suboxic zone with $\mathrm{Mn}$ reduction (and denitrification) separating the upper and lower oxic zones in the sediment column (22KL in Fig. 3). If sediment thickness further increases, the suboxic 
zone expands downward, eventually reaching beyond the core bottom, so that only the downward-decreasing pore-water $\mathrm{Mn}^{2+}$ concentrations indicate the presence of $\mathrm{O}_{2}$ deeper in the sediment (9KL, 108SL in Fig. 3). The observation that $\mathrm{O}_{2}$ diffuses further upward in the sediments near faults that reach from the basement into the sediments (81SL in Fig. 3) demonstrates that faulting facilitates upward transport of $\mathrm{O}_{2}$. The consumption of $\mathrm{O}_{2}$ by reduced phases within the sediments may release nitrate and inorganic carbon to the pore-water, where they subsequently diffuse downward into the basement. In this way, the reaction of oxygen within the sediments also contributes to changes in fluid composition (Orcutt et. al., 2013) and the percolating fluids in the basement may act as a transport pathway of these oxidation products back to the ocean.

The heat-flow values, which are slightly higher than the theoretical values of conductive cooling at the locations of cores 69SL (Fig. 2) and 117SL (Figs. 1 and 3), cannot be explained by a decrease in sediment thickness but suggest that temperatures at the sediment-basement interface are elevated relative to temperatures at this depth in the close vicinity. However, we did not find a single site with extremely high heat flow.

\section{CONCLUSIONS}

Our study at a typical, 18-22 Ma ridge flank adds a comprehensive data set of seismic, heatflow, sediment pore-water, and solid-phase data to the global observations of heat and mass transfer on ridge flanks. Despite the limited areal coverage of our survey, we are confident that the clear signals for vigorous hydrothermal circulation in the upper crust are representative for a large area of the western flank of the East Pacific Rise comprising tens of thousands of square kilometers. If the residence time of the fluids in the upper crust is short or the fluid flux is large, the fluids would remain oxic, and $\mathrm{O}_{2}$ could diffuse upwards into the overlying sediments and react with them. This would result in diffusive downward transport of oxidized reaction products $\left(\mathrm{CO}_{2}, \mathrm{NO}_{3}\right)$ from the sediment into the basement fluid, and with this fluid, these products would be transported back into the water column.

To date, the exchange of elements and substances between sediment and ocean water has been thought to be a direct exchange between ocean and sediment operating from above. However, there seems to be a similar, albeit "indirect," exchange that affects the sediments from below and operates via the fluids percolating through the ocean crust. This "indirect" ventilation is important for remobilization of the residual reduced material in the deep sediments and for bringing it back into the ocean.

\section{ACKNOWLEDGMENTS}

We thank captain Lutz Mallon and the crew of the German research vessel SONNE for the excellent cooperation and the pleasant atmosphere during cruise
SO-240. A. Lamparter from the Federal Institute for Geosciences and Natural Resources (BGR) carried out the permeability measurements, for which we are grateful. The manuscript was improved by comments from A. Fisher, L. Coogan, and an anonymous reviewer. This work was funded by the German Federal Ministry of Education and Research (BMBF) under grant 03G0240A-D, and by internal funding from BGR and the Helmholtz Association.

\section{REFERENCES CITED}

Baker, P.A., Stout, P.M., Kastner, M., and Elderfield, H., 1991, Large-scale lateral advection of seawater through oceanic crust in the central equatorial Pacific: Earth and Planetary Science Letters, v. 105, p. 522-533, doi:10.1016/0012-821X(91) 90189-O.

Barckhausen, U., Bagge, M., and Wilson, D.S., 2013, Seafloor spreading anomalies and crustal ages of the Clarion-Clipperton zone: Marine Geophysical Research, v. 34, p. 79-88, doi:10.1007 /s11001-013-9184-6.

Fisher, A.T., 2005, Marine hydrogeology: Recent accomplishments and future opportunities: Hydrogeology Journal, v. 13, p. 69-97, doi:10.1007 /s10040-004-0400-y.

Fisher, A.T., and Becker, K., 2000, Channelized fluid flow in oceanic crust reconciles heat-flow and permeability data: Nature, v. 403, p. 71-74, doi: $10.1038 / 47463$

Fisher, A.T., Giambalvo, E., Sclater, J., Kastner, M., Ransom, B., Weinstein, Y., and Lonsdale, P., 2001, Heat flow, sediment and pore fluid chemistry, and hydrothermal circulation on the east flank of Alarcon Ridge, Gulf of California: Earth and Planetary Science Letters, v. 188, p. 521-534, doi:10.1016/S0012-821X(01)00310-7.

Fisher, A.T., Stein, C.A., Harris, R.N., Wang, K., Silver, E.A., Pfender, M., and Villinger, H., 2003, Abrupt thermal transition reveals hydrothermal boundary and role of seamounts within the Cocos plate: Geophysical Research Letters, v. 30, 1550, doi:10.1029/2002GL016766.

Hasterok, D., 2013, A heat flow based cooling model for tectonic plates: Earth and Planetary Science Letters, v. 361, p. 34-43, doi:10.1016/j.epsl.2012 10.036 .

Hasterok, D., Chapman, D.S., and Davis, E.E., 2011, Oceanic heat flow: Implications for global heat loss: Earth and Planetary Science Letters, v. 311, p. 386-395, doi:10.1016/j.eps1.2011.09.044.

Hutnak, M., and Fisher, A.T., 2007, Influence of sedimentation, local and regional hydrothermal circulation, and thermal rebound on measurements of seafloor heat flux: Journal of Geophysical Research, v. 112, B12101, doi:10.1029/2007JB005022.

Kawada, Y., Seama, N., and Urabe, T., 2011, The role of seamounts in the transport of heat and fluids: Relations among seamount size, circulation patterns, and crustal heat flow: Earth and Planetary Science Letters, v. 306, p. 55-65, doi:10.1016/j .eps1.2011.03.029.

Kuhn, T., and Shipboard Scientific Party, 2015, LowTemperature Fluid Circulation at Seamounts and Hydrothermal Pits: Heat Flow Regime, Impact on Biogeochemical Processes and its Potential Influence on the Occurrence and Composition of Manganese Nodules in the NE Pacific: Hannover, Germany, Bundesanstalt für Geowissenschaften und Rohstoffe (BGR), Cruise Report SO240/ FLUM, 185 p., doi:10.2312/cr_so240.

Mewes, K., Mogollón, J.M., Picard, A., Rühlemann, C., Kuhn, T., Nöthen, K., and Kasten, S., 2014, Impact of depositional and biogeochemical processes on small-scale variations in nodule abundance in the Clarion-Clipperton Fracture Zone: Deep-Sea Research I, Oceanographic Research
Papers, v. 91, p. 125-141, doi:10.1016/j.dsr.2014 .06 .001 .

Mewes, K., Mogollón, J.M., Picard, A., Rühlemann, C., Eisenhauer, A., Kuhn, T., Ziebis, W., and Kasten, S., 2016, Diffusive transfer of oxygen from seamount basaltic crust into overlying sediments: An example from the Clarion-Clipperton Fracture Zone: Earth and Planetary Science Letters, v. 433, p. 215-225, doi:10.1016/j.eps1.2015.10.028.

Mogollón, J.M., Mewes, K., and Kasten, S., 2016, Quantifying manganese and nitrogen cycle coupling in manganese-rich, organic carbon-starved marine sediments: Examples from the Clarion-Clipperton Fracture Zone: Geophysical Research Letters, v. 43, p. 7114-7123, doi:10.1002/2016GL069117.

Orcutt, B.N., Wheat, C.G., Rouxel, O., Hulme, S., Edwards, K.J., and Bach, W., 2013, Oxygen consumption rates in subseafloor basaltic crust derived from a reaction transport model: Nature Communications, v. 4, p. 2539, doi:10.1038/ncomms3539.

Rühlemann, C., Kuhn, T., Wiedicke, M., Kasten, S. Mewes, K., and Picard, A., 2011, Current status of manganese nodule exploration in the German license area, in Proceedings of the Ninth International Society of Offshore and Polar Engineers (ISOPE) Ocean Mining Symposium: Maui, Hawaii, 19-24 June: Cupertino, California, International Society of Offshore and Polar Engineers, p. 168-173, http://www.isope.org/publications/ proceedings/ISOPE_OMS/OMS\%202011/data/ papers/M11-27Ruhlemann.pdf.

Sclater, J.G., 2003, Ins and outs on the ocean floor: Nature, v. 421, p. 590-591, doi:10.1038/421590a.

Sclater, J.G., Crowe, J., and Anderson, R.N., 1976, On the reliability of oceanic heat flow averages: Journal of Geophysical Research, v. 81, p. 2997-3006, doi:10.1029/JB081i017p02997.

Spinelli, G.A., Giambalvo, E.R., and Fisher, A.T., 2004, Sediment permeability, distribution, and influence on fluxes in oceanic basement, in Davis, E.E., and Elderfield, H., eds., Hydrogeology of the Oceanic Lithosphere: Cambridge, UK, Cambridge University Press, p. 151-188.

Stein, C., and Stein, S., 1992, A model for the global variation in oceanic depth and heat flow with lithospheric age: Nature, v. 359, p. 123-129, doi: 10.1038/359123a0.

Villinger, H.W., Trehu, A.M., and Grevemeyer, I., 2010, Seafloor marine heat flux measurements and estimation of heat flux from seismic observations of bottom simulating reflectors, in Riedel, M., et al., eds., Geophysical Characterization of Gas Hydrates: Tulsa, Oklahoma, Society of Exploration Geophysicists, p. 279-300, doi:10.1190 /1.9781560802197.ch18.

Villinger, H.W., Pichler, T., Kaul, N., Stephan, S., Pälike, H., and Stephan, F., 2017, Formation of hydrothermal pits and the role of seamounts in the Guatemala Basin (equatorial East Pacific) from heat flow, seismic, and core studies: Geochemistry Geophysics Geosystems, v. 18, p. 369-383, doi: 10.1002/2016GC006665.

Winslow, D.M., and Fisher, A.T., 2015, Sustainability and dynamics of outcrop-to-outcrop hydrothermal circulation: Nature Communications, v. 6 , p. 7567, doi:10.1038/ncomms8567.

Ziebis, W., McManus, J., Ferdelman, T., Schmidt-Schierhorn, F., Bach, W., Muratli, J., Edwards, K.J., and Villinger, H., 2012, Interstitial fluid chemistry of sediments underlying the North Atlantic gyre and the influence of subsurface fluid flow: Earth and Planetary Science Letters, v. 323-324, p. 79-91, doi:10.1016/j.eps1.2012.01.018.

Manuscript received 23 February 2017 Revised manuscript received 4 May 2017 Manuscript accepted 4 May 2017

Printed in USA 